\title{
Effect of olive storage period at two different temperatures on oil quality of two tunisian cultivars of Olea europea, Chemlali and Chétoui
}

\author{
Ben Youssef Nabil ${ }^{1,2 *, \#}$, Ouni Youssef ${ }^{1,2 \#,}$, Dabbech Nizar ${ }^{2}$, Baccouri Bechir ${ }^{2}$, Abdelly Chedly \\ and Zarrouk Mokhtar ${ }^{2}$ \\ ${ }^{1}$ Laboratoire des Plantes extrêmophiles, Centre de Biotechnologie de Borj-Cedria, B.P. 901, 2050. \\ Hammam-Lif, Tunisia. \\ ${ }^{2}$ Laboratoire Caractérisation et Qualité de l'huile d'Olive, Centre de Biotechnologie de Borj-Cedria, B.P. 901, 2050. \\ Hammam-Lif, Tunisia. \\ Accepted 7 December, 2010
}

\begin{abstract}
Chétoui and Chemlali olive fruits were stored at two different temperatures (ambient and $5^{\circ} \mathrm{C}$ ) for different periods before oil extraction at $0,7,14,21$ and 28 days to investigate the effect of postharvest fruit storage on olive oil quality. Conventional analyses (acidity, peroxide value, specific extinction coefficient at 232 and $270 \mathrm{~nm}$ and fatty acid composition) and non conventional analyses (pigments, total phenols, oxidative stability and radical scavenging capacity) were carried out in order to evaluate the oil quality. Results showed that fruit storage at ambient temperature led to the deterioration of the oil parameter qualities such as acidity, K232 and K270 which is more rapidly in Chemlali oils than that of Chétoui cultivar. In the same way, the trend of total phenols, oxidative stability and radical scavenging capacity of the studied olive oils showed a decrease during the fruit storage at ambient temperature. This reduction was more severe in Chemlali olive oils than those of Chétoui cultivar. Storage of fruits at $5^{\circ} \mathrm{C}$ prevented the fast alteration that is produced in oils extracted from fruits stored at ambient temperature.
\end{abstract}

Key words: Olive storage, oil quality, fatty acids, stability.

\section{INTRODUCTION}

Virgin olive oil is a valuable vegetable oil extracted from fresh and healthy olive fruits (Olea europeae L.) by mechanical processes and without any preliminary refining (Garcia and Yousfi, 2006). It has an excellent nutritional, sensorial and functional qualities (Matos et al., 2007), and is a product of major economical importance

*Corresponding author. E-mail: nabilbtn@gmail.com, Tel: +216.79 .325 .848 . Fax: +216.79 .325 .638 .

Abbreviations: DPPH, 1,1-Diphenyl-2-picrylhydrazyl radical; RSA, radical scavenging activity; PV, peroxide value; MUFA, monounsaturated fatty acid; SFA, saturated fatty acids; PUFA, polyunsaturated fatty acid.

\#The first two authors contributed equally to this work. in the Mediterranean area. Regarding the wholesome advantages of olive oil consumption, it owns a high antioxidant capability and reduces the risk of suffering from cardiovascular diseases and contracting breast or colon cancers (Medeiros, 2001; Gimeno et al., 2002; Alberti et al., 2009; Menendez et al., 2009; Cicerale et al., 2010; Gigon and Le Jeune, 2010). Due to its components been beneficial to human health and content of other functional food compounds, interest in olive oil as a healthy food source has also increased outside the Mediterranean region (Bandelj et al., 2002; Ceci and Carelli, 2010). Tunisia is next to Spain, Italy and Greece in the world olive oil sector regarding the number of trees and olive oil production. Tunisia produced $144500 \mathrm{~T}$ per year between 2000 and 2006 (Codex Alimenarius Commission, 2007 ), accounting for $\sim 5.2 \%$ of world production and is considered to rank second one with regard to surface use. In Tunisia, there are two main olive cultivars, Chétoui 
in the northern regions and Chemlali in the central and southern regions. These two varieties account for $95 \%$ of the total olive tree orchards and contribute more than $90 \%$ of the national production of olive oil. Chemlali alone occupies more than two thirds of the total olive growing area. The Chétoui cultivar is the second main variety cultivated in Tunisia and is widespread in the plains as well in mountain regions. In addition to the effects of cultivars, the degree of fruit ripeness, and the industrial processes employed for oil extraction, as well as the quality of the fruit from which oil is extracted has a great effect on olive oil quality (Garcia and Yousfi, 2006). At the harvest period, processing capacity of the mills was often exceeded by Tunisian olive production. Olives are often piled into large heaps and could be stored at ambient temperature for up to several days prior to processing for oil extraction. Pressure within the olive pile during storage may cause secretion of fluid from the olives thereby providing an optimum medium for the growth of fungi and bacteria (Olias and Garcia, 1997). These conditions may accelerate the deterioration of the fruit and eventually cause losses in the olive oil quality. Despite the economic importance of Tunisian olive sector, there is scarce information available on the influence of the storage conditions on the olive oil quality of Tunisian cultivars. The objective of the present study is to investigate the effect of temperatures and periods of olive storage on oil quality of the two main Tunisian cultivars, Chemlali and Chétoui.

\section{MATERIALS AND METHODS}

\section{Samples}

Olive fruits from Chemlali and Chétoui cultivars were handpicked during the crop season 2007 - 2008 in Kairouan (central Tunisia, semi-arid stage) and Grombelia (north-eastern Tunisia, sub-humid stage), respectively. The olives were randomly picked at the optimal ripening stage (at the end of December), according to their fruit colour in both skin and pulp. After harvest, olive fruits were immediately transported to the laboratory and were divided into lots of $15 \mathrm{~kg}$. The reference sample was processed immediately after harvesting, while the other lots were stored in open plastic containers during $7,14,21$ and 28 days of storage at $5^{\circ} \mathrm{C}$ and ambient temperature. From each lot, a $1 \mathrm{~kg}$ sample was randomly taken after the determined storage period and submitted separately to oil extraction. Using an Abencor analyzer (MC2 Ingenierias y Sistemas, Sevilla, Spain), the fruits were crushed with a hammer crusher, and the paste was mixed at $25^{\circ} \mathrm{C}$ for $30 \mathrm{~min}$, centrifuged without addition of warm water. The oil was transferred into amber glass bottles and stored in the dark at $4^{\circ} \mathrm{C}$ until the moment of analysis. Three replicates were prepared of all samples.

\section{Determination of oil quality parameters}

Free acidity, expressed as percent of oleic acid (\% 18:1), peroxide value, given as milliequivalents of active oxygen per kilogram of oil $\left(\mathrm{meqO}_{2} / \mathrm{kg}\right)$, and UV absorption characteristics (K232 and K270) were determined according to the analytical methods described in the European Union Commission Regulations EEC/2568/91 and EEC/1429/92.

\section{Determination of chlorophyll and carotenoid contents}

Chlorophyll and carotenoid contents were determined colorimetrically following the method of Minguez et al. (1991). The maximum absorption at $670 \mathrm{~nm}$ is related to the chlorophyll fraction, while the maximum absorption at $470 \mathrm{~nm}$ is related to the carotenoid fraction. The values of the coefficients of specific extinction applied were E0 $=613$ for pheophytin, a major component in the chlorophyll fraction, and $E 0=2000$ for lutein, a major component in the carotenoid fraction. Thus, the pigment contents were calculated as follows:

Chlorophyll $(\mathrm{mg} / \mathrm{kg})=\left(\mathrm{A}_{670} \times 10^{6}\right) /(613 \times 100 \times \mathrm{d})$

Carotenoid $(\mathrm{mg} / \mathrm{kg})=\left(\mathrm{A}_{470} \times 10^{6}\right) /(2000 \times 100 \times \mathrm{d})$

Where, $A$ is the absorbance and $d$ is the spectrophotometer cell thickness $(1 \mathrm{~cm})$. Chlorophyll and carotenoid contents were expressed as milligrams of pheophytin ' $a$ ' or lutein per kilogram of oil, respectively.

\section{Determination of fatty acid composition}

The fatty acid composition of the oil was determined by gas chromatography (GC) according to the method of European Regulation 2568/91. Methyl esters were prepared by vigorous shaking of a solution of each olive oil sample in n-hexane $(0.2 \mathrm{~g}$ in 3 $\mathrm{mL}$ ) with $0.4 \mathrm{~mL} 2 \mathrm{~N}$ methanolic potassium hydroxide solution. Chromatographic analysis was performed on a Hewlett Packard 4890D gas chromatograph (Hewlett-Packard Company, Wilmington, DE, USA), equipped with a capillary column (Supelcowax-10: $30 \mathrm{~m}$ $\times 0.53 \mathrm{~mm} \times 0.25 \mu \mathrm{m}$ ), an injector split-splitless and a FID detector. The carrier gas was nitrogen, with a flow rate of $1 \mathrm{mlmn}^{-1}$. The temperatures of the injector, the detector and the oven were held at 230,250 and $210^{\circ} \mathrm{C}$, respectively. Fatty acids were identified by comparing retention times with those of standard compounds.

\section{Determination of total phenol content}

Total phenol contents were quantified colorimetrically according to the procedure described by Ranalli et al. (1999). Phenolic compounds were isolated by triple extraction of a solution of oil $(10 \mathrm{~g})$ in hexane $(25 \mathrm{ml})$ with a methanol-water mixture $(60: 40, \mathrm{v} / \mathrm{v})$. The Folin-Ciocalteau reagent (Merck Schuchardt OHG, Hohenbrunn, Germany) was added to a suitable aliquot of the combined extracts, and the absorption of the solution at $725 \mathrm{~nm}$ was measured. Values are given as milligrams of caffeic acid per kilogram of oil.

\section{Determination of oil oxidative stability}

Oxidative stability was evaluated by the Rancimat method. Stability was expressed as the oxidation induction time (hours) measured with the Rancimat 743 apparatus (Metrohm, Herisau Switzerland), using $3.5 \mathrm{~g}$ of oil. A flow of air $(10 \mathrm{~L} / \mathrm{h})$ was bubbled through the oil heated at $102^{\circ} \mathrm{C}$ and collected in cold water, whose conductivity increased progressively. The time taken to reach a fixed level of conductivity was measured (Gutiérrez, 1989).

\section{Determination of the oil radical scavenging capacity}

The capacity to scavenge the stable 1,1-diphenyl-2-picrylhydrazyl radical (DPPH) was monitored according to the method of Kalantzakis et al. (2006). $1 \mathrm{~mL}$ of the oil solution in ethyl acetate $(10 \%, \mathrm{w} / \mathrm{v})$ was added to $4 \mathrm{~mL}$ of a freshly prepared $\mathrm{DPPH}$ solution $\left(10^{-4} \mathrm{M}\right.$ in ethyl acetate) in a screwcapped $10 \mathrm{~mL}$ test tube. The 
Table 1. Changes in some analytical parameters (acidity, peroxide value, K232, K270, chlorophylls and carotenoids) of 'Chétoui' and 'Chemlali' oils obtained from olives stored at ambient temperature and $5^{\circ} \mathrm{C}$.

\begin{tabular}{|c|c|c|c|c|c|c|c|c|}
\hline Variety & TS & $\begin{array}{c}\text { PS } \\
\text { (days) }\end{array}$ & $\begin{array}{c}\text { Acidity } \\
(\% \text { C18 : 1) }\end{array}$ & $\begin{array}{c}\text { Peroxide Value } \\
\left(\mathrm{meqO}_{2} / \mathrm{kg}\right)\end{array}$ & K232 & K270 & $\begin{array}{c}\text { Chlorophylls } \\
(\mathrm{mg} / \mathrm{kg})\end{array}$ & $\begin{array}{c}\text { Carotenoids } \\
(\mathrm{mg} / \mathrm{kg})\end{array}$ \\
\hline \multirow[t]{10}{*}{ Chemlali } & AT & 0 & $0.35 \pm 0.05^{\mathrm{C}}$ & $2.50 \pm 0.50^{\mathrm{d}}$ & $1.87 \pm 0.15^{\mathrm{c}}$ & $0.09 \pm 0.01^{\mathrm{e}}$ & $2.58 \pm 0.22^{\mathrm{a}}$ & $1.11 \pm 0.10^{\mathrm{a}}$ \\
\hline & & 7 & $0.83 \pm 0.03^{\mathrm{c}}$ & $4.17 \pm 0.29^{c}$ & $2.26 \pm 0.14^{b}$ & $0.15 \pm 0.01^{d}$ & $1.68 \pm 0.11^{b}$ & $1.05 \pm 0.07^{\mathrm{a}}$ \\
\hline & & 14 & $1.35 \pm 0.10^{\mathrm{b}}$ & $10.83 \pm 0.76^{b}$ & $2.91 \pm 0.16^{\mathrm{a}}$ & $0.21 \pm 0.01^{\mathrm{c}}$ & $1.56 \pm 0.12^{b}$ & $1.01 \pm 0.07^{\mathrm{a}}$ \\
\hline & & 21 & $2.72 \pm 0.15^{\mathrm{ab}}$ & $12.00 \pm 0.87^{b}$ & $3.03 \pm 0.03^{\mathrm{a}}$ & $0.29 \pm 0.01^{b}$ & $1.51 \pm 0.10^{b}$ & $1.04 \pm 0.07^{\mathrm{a}}$ \\
\hline & & 28 & $4.75 \pm 0.38^{a}$ & $15.17 \pm 1.15^{\mathrm{a}}$ & $2.96 \pm 0.15^{\mathrm{a}}$ & $0.31 \pm 0.01^{\mathrm{a}}$ & $1.44 \pm 0.09^{b}$ & $0.93 \pm 0.07^{\mathrm{a}}$ \\
\hline & $5^{\circ} \mathrm{C}$ & 0 & $0.35 \pm 0.05^{\mathrm{c}}$ & $2.50 \pm 0.50^{c}$ & $1.87 \pm 0.15^{\mathrm{C}}$ & $0.09 \pm 0.01^{d}$ & $2.58 \pm 0.22^{\mathrm{a}}$ & $1.11 \pm 0.10^{\mathrm{a}}$ \\
\hline & & 7 & $0.38 \pm 0.03^{c}$ & $4.83 \pm 0.29^{b}$ & $2.09 \pm 0.17^{\mathrm{bc}}$ & $0.10 \pm 0.00^{d}$ & $2.16 \pm 0.21^{b}$ & $1.18 \pm 0.11^{\mathrm{a}}$ \\
\hline & & 14 & $0.42 \pm 0.06^{\mathrm{c}}$ & $6.33 \pm 0.76^{b}$ & $2.24 \pm 0.09^{\mathrm{ab}}$ & $0.13 \pm 0.01^{c}$ & $2.09 \pm 0.11^{\mathrm{b}}$ & $1.15 \pm 0.13^{\mathrm{a}}$ \\
\hline & & 21 & $0.67 \pm 0.03^{b}$ & $11.00 \pm 1.73^{\mathrm{a}}$ & $2.38 \pm 0.06^{\mathrm{a}}$ & $0.15 \pm 0.01^{b}$ & $1.99 \pm 0.14^{\mathrm{bc}}$ & $1.14 \pm 0.05^{\mathrm{a}}$ \\
\hline & & 28 & $0.82 \pm 0.07^{\mathrm{a}}$ & $12.00 \pm 1.32^{\mathrm{a}}$ & $2.46 \pm 0.12^{\mathrm{a}}$ & $0.17 \pm 0.01^{\mathrm{a}}$ & $1.73 \pm 0.15^{c}$ & $1.06 \pm 0.05^{\mathrm{a}}$ \\
\hline \multirow[t]{10}{*}{ Chétoui } & AT & 0 & $0.43 \pm 0.03^{d}$ & $2.00 \pm 0.50^{d}$ & $1.12 \pm 0.12^{d}$ & $0.05 \pm 0.00^{\mathrm{a}}$ & $2.63 \pm 0.14^{a}$ & $1.12 \pm 0.03^{\mathrm{a}}$ \\
\hline & & 7 & $0.63 \pm 0.07^{c d}$ & $2.50 \pm 0.50^{d}$ & $1.67 \pm 0.11^{c}$ & $0.07 \pm 0.01^{b}$ & $2.38 \pm 0.15^{a}$ & $1.00 \pm 0.10^{\mathrm{a}}$ \\
\hline & & 14 & $0.77 \pm 0.06^{\mathrm{c}}$ & $6.00 \pm 0.50^{c}$ & $2.21 \pm 0.07^{b}$ & $0.15 \pm 0.01^{c}$ & $1.99 \pm 0.21^{b}$ & $1.03 \pm 0.01^{\mathrm{a}}$ \\
\hline & & 21 & $2.32 \pm 0.20^{b}$ & $8.17 \pm 0.76^{\mathrm{b}}$ & $2.33 \pm 0.13^{\mathrm{ab}}$ & $0.17 \pm 0.01^{d}$ & $1.54 \pm 0.13^{\mathrm{c}}$ & $0.97 \pm 0.10^{\mathrm{a}}$ \\
\hline & & 28 & $2.95 \pm 0.26^{\mathrm{a}}$ & $10.83 \pm 0.76^{\mathrm{a}}$ & $2.42 \pm 0.10^{\mathrm{a}}$ & $0.21 \pm 0.01^{\mathrm{e}}$ & $1.33 \pm 0.09 c$ & $1.00 \pm 0.10^{\mathrm{a}}$ \\
\hline & $5^{\circ} \mathrm{C}$ & 0 & $0.43 \pm 0.03^{\mathrm{c}}$ & $2.00 \pm 0.50^{c}$ & $1.12 \pm 0.12^{d}$ & $0.05 \pm 0.00^{c}$ & $2.63 \pm 0.14^{\mathrm{a}}$ & $1.12 \pm 0.03^{\mathrm{a}}$ \\
\hline & & 7 & $0.45 \pm 0.05^{\mathrm{c}}$ & $2.50 \pm 0.50^{\mathrm{bc}}$ & $1.65 \pm 0.14^{\mathrm{c}}$ & $0.07 \pm 0.01^{c}$ & $2.35 \pm 0.17^{b}$ & $1.07 \pm 0.11^{\mathrm{a}}$ \\
\hline & & 14 & $0.50 \pm 0.05^{\mathrm{c}}$ & $3.17 \pm 0.28^{\mathrm{b}}$ & $1.80 \pm 0.14^{b c}$ & $0.12 \pm 0.01^{b}$ & $2.08 \pm 0.15^{c}$ & $1.06 \pm 0.09^{\mathrm{a}}$ \\
\hline & & 21 & $0.65 \pm 0.05^{b}$ & $7.00 \pm 0.50^{\mathrm{a}}$ & $2.00 \pm 0.14^{b}$ & $0.14 \pm 0.01^{\mathrm{ab}}$ & $1.89 \pm 0.11^{c}$ & $1.00 \pm 0.01^{\mathrm{a}}$ \\
\hline & & 28 & $0.75 \pm 0.05^{\mathrm{a}}$ & $7.33 \pm 0.76^{\mathrm{a}}$ & $2.20 \pm 0.13^{\mathrm{a}}$ & $0.16 \pm 0.03^{\mathrm{a}}$ & $1.06 \pm 0.10^{d}$ & $1.02 \pm 0.14^{\mathrm{a}}$ \\
\hline EVOO & & & $\leq 0.8 \%$ & $\leq 20$ & $\leq 2.5$ & $\leq 0.22$ & - & - \\
\hline
\end{tabular}

Data are expressed as mean values \pm SD of three independent experiments. Duncan's test has been used to assess significance (Duncan's test, $p=$ 0.05).

Significant differences in the same row are shown by different letters.TS: Temperature storage; PS: period storage; AT: ambient temperature; EVOO: extra virgin olive oil.

reaction mixture was then shaken vigorously for $10 \mathrm{~s}$ in a Vortex apparatus, and the tube was maintained in the dark for $30 \mathrm{~min}$, after which a steady state was reached. The absorbance of the mixture was measured at $515 \mathrm{~nm}$ against a blank solution. The radical scavenging activity (RSA) toward DPPH was expressed as the \% reduction in DPPH concentration by the constituents of the oils:

$\%[\mathrm{DPPH}]_{\mathrm{red}}=100-\left(1[\mathrm{DPPH}]_{30} /[\mathrm{DPPH}]_{0}\right)$

Where, $[\mathrm{DPPH}]_{0}$ and $[\mathrm{DPPH}]_{30}$ were the concentrations of $\mathrm{DPPH}$ in the control sample $(t=0)$ and in the test mixture after the 30 min reaction, respectively.

\section{Statistical analysis}

The results are expressed as means. Data were compared on the basis of SD of the mean values. In addition, Duncan's multiple range tests were used to determine significant differences among data. Statistical analysis was performed using the Statistica 5.0 package (StatSoft'97 edition).

\section{RESULTS AND DISCUSSION}

Table 1 shows the analytical results, determined in the two cultivars, of acidity, peroxide value (PV), K232 and
K270, chlorophyll and carotenoid contents, of olive oil produced from olives after harvesting $(0)$ and stored for $7,14,21$ and 28 days at ambient temperature and $5^{\circ} \mathrm{C}$.

\section{Change in acidity}

The oils extracted immediately post-harvest had an average acidity values of 0.57 and $0.53 \%$ for Chemlali and Chétoui cultivars, respectively and were therefore categorized as extra virgin olive oil. Free acidity depended on the period of time from harvesting to processing, with the storage temperature being the most important factor. Thus, for Chemlali cultivar, acidity remained practically stable in samples stored at $5^{\circ} \mathrm{C}$ with a very slight rise at the last period storage (28 days) reaching the upper limit of extra virgin category $(0.8 \%)$. At ambient temperature, it increased considerably exceeding just after 7 days of fruit storage. This process was accelerated and after 28 days of storage, the oil acidity had reached 14 times the initial values. For Chétoui cultivar, all the analysed oils from stored olives at $5^{\circ} \mathrm{C}$ showed low values of acidity which were within the limit of the extra virgin category. By contrast, oil acidity from stored olives 
kept at ambient temperature increased considerably exceeding largely, after three weeks of storage, the established limit of extra virgin classification. In the other hand, the rise of acidity level observed in the Chemlali oils obtained from olives stored at ambient temperature was faster and more accentuated than those of Chétoui cultivar. In cold storage, both cultivars seem to have the same trend. These results agree with the finding of other workers which reported that the increase in oil acidity during storage is positively related to increasing storage temperature for Spanish, Italian and Greek varieties (Clodoveo et al., 2007; Koprivnjak et al., 2002; Kiritsakis et al., 1998; Agar et al., 1998; Garcia et al., 1996). The increase in acidity was probably the result of the fruit deterioration as a consequence of pathogenic microorganisms process which induces hydrolytic activity and leads to the release of fatty acids from the triacylglycerol molecules of the oil (Clodoveo et al., 2007). This process can be accelerated by the temperature increase caused by fruit fermentation and by mechanical damage as a compression consequence (Garcia et al., 1996; Castellano et al., 1993). It is clear that Chemlali was the cultivar that is more susceptible to this action. This fact would seem related to the brittleness of the pericarp of the Chemlali olives which are finer and more permeable and which makes them easily contestable by the microorganisms (Trigui et al., 2002; Turki and Mahjoub, 1995). Cold storage avoids this pathogenic activity and allows oil acidity to be maintained below $0.8 \%$ for up to 28 days.

\section{Change in peroxide value (PV)}

Peroxide value of oils obtained from stored olives increased during storage, compared to oil from freshly harvested olives (Table1). As observed in free acidity, this behaviour was apparently more accentuated for Chemlali cultivar. It was probably a consequence of the higher action of fruit lipoxygenases and cold storage at $5^{\circ} \mathrm{C}$ significantly delayed the rise in the PV of the oils. At the end of the observation trial ( 28 days), none of the oils analyzed exceeded the maximum peroxide value for extra virgin olive oil category ( $20 \mathrm{meq} \mathrm{O} 2 / \mathrm{kg}$ ) since the highest PV obtained was on average 15.2 meq O2/ $\mathrm{kg}$ for oils extracted from Chemlali olives stored at ambient temperature for 28 days. Results of this study agree with findings of previous works (Agar et al., 1998; Garcia et al., 1996; Guttierrez et al., 1992).

\section{Change in UV spectrophotometric indices}

The specific extinction coefficient at $232 \mathrm{~nm}$ wavelength, $\mathrm{K} 232$, is related to the primary oxidation of oil and is an indication of conjugation of polyunsaturated fatty acids, whereas K270 is an indication of carbonylic compounds (aldehydes and ketones) in olives and is related to the secondary oxidation products (Boskou, 1996; Garcia et al., 1996). UV-specific extinction determination permits an approximation of the oxidation process in unsaturated oils (Gutiérrez et al., 1992). In spite of a regular increase in these parameters during olive storage at $5^{\circ} \mathrm{C}$, the values remain always below the limits established for extra virgin olive oils for the two olive cultivars (Table 1). These results are consistent with the findings of Clodoveo et al. (2007) and Garcia et al. (1996). For olives stored at ambient temperature, it is clear that Chétoui cultivar behaves better since none of the two UV indices exceeded the established limits of extra virgin category whereas for Chemlali cultivar, a marked increase was observed in these parameters exceeding the maximum K232 and K270 value for extra virgin olive oil category after 14 and 21 days of storage, respectively.

\section{Change in pigment contents}

The presence of pigments not only determines the colour of the product but also plays an important role in the oxidative activity of processed foodstuff, due to their antioxidant nature in the dark and pro-oxidant activity in the light (Oueslati et al., 2009). These substances also have biological and health proprieties and occur in the oil at concentrations which usually correlate with those of phenols (Ranalli and Modest, 1999). During fruit ripening and oil storage, they undergo a natural breakdown which parallels that of phenols; consequently they could be considered as a product freshness indicator (GandulRojas et al., 1999). Changes in pigment content are presented in Table 1. The results showed similar behaviour for the two olive cultivars studied with a decrease in oils extracted from fruit stored under the two temperature conditions concerning chlorophyll amount whereas the carotenoid content did not change markedly. Kiritsakis et al. (1998) have also found that oil from $5^{\circ} \mathrm{C}$ stored olives had slightly less chlorophyll content than oil from freshly harvested olives of Koroneiki cultivar.

\section{Change in fatty acid composition}

Table 2 gives the fatty acids composition for the two cultivars studied. Identified fatty acids were: Palmitic (C16:0), palmitoleic (C16:1), stearic (C18:0), oleic (C18:1), linoleic (C18:2), linolenic (C18:3) and arachidic (C20:0). Palmitic, oleic and linoleic were measured as major fatty acids. Palmitoleic, stearic, linolenic and arachidic acids were determined in small amounts in all studied olive oils. The oleic acid which contributes to the oil stability and its quality, is the main monounsaturated fatty acid (MUFA) in all the samples and is present in higher concentrations which never decreases less than $57 \%$ of the total fatty acid. Chétoui olive oil samples were found to show a higher content in total MUFA, due to 
Table 2. Fatty acid composition of the studied olive oil samples.

\begin{tabular}{|c|c|c|c|c|c|c|c|c|c|c|c|c|}
\hline Variety & TS & $\begin{array}{l}\text { PS } \\
\text { (day } \\
\text { s) }\end{array}$ & $16: 00$ & 16:01 & 18:00 & $18: 01$ & $18: 02$ & $18: 03$ & 20:00 & SFA & MUFA & PUFA \\
\hline \multirow{10}{*}{ Chemlali } & \multirow{5}{*}{ AT } & 0 & $19.72 \pm 1.25^{\mathrm{a}}$ & $2.48 \pm 0.38^{\mathrm{bc}}$ & $2.06 \pm 0.07^{\mathrm{ab}}$ & $57.91 \pm 1.39^{b}$ & $16.79 \pm 0.24^{a}$ & $0.67 \pm 0.01^{a}$ & $0.37 \pm 0.14^{\mathrm{a}}$ & $22.15 \pm 1.15^{a}$ & $60.38 \pm 1.35^{b}$ & $17.46 \pm 0.25^{a}$ \\
\hline & & 7 & $19.09 \pm 0.44^{\mathrm{ab}}$ & $3.02 \pm 0.29^{a}$ & $1.95 \pm 0.03^{b}$ & $58.00 \pm 0.92^{b}$ & $16.93 \pm 0.69^{a}$ & $0.64 \pm 0.04^{a}$ & $0.38 \pm 0.05^{\mathrm{a}}$ & $21.42 \pm 0.43^{\mathrm{ab}}$ & $61.02 \pm 0.68^{a b}$ & $17.56 \pm 0.73^{\mathrm{a}}$ \\
\hline & & 14 & $18.98 \pm 0.99^{\mathrm{ab}}$ & $2.73 \pm 0.18^{\mathrm{ab}}$ & $1.98 \pm 0.01^{b}$ & $58.14 \pm 0.43^{b}$ & $17.12 \pm 0.80^{\mathrm{a}}$ & $0.67 \pm 0.04^{\mathrm{a}}$ & $0.38 \pm 0.06^{\mathrm{a}}$ & $21.34 \pm 0.96^{\mathrm{ab}}$ & $60.87 \pm 0.28^{\mathrm{ab}}$ & $17.79 \pm 0.84^{\mathrm{a}}$ \\
\hline & & 21 & $17.62 \pm 0.54^{b}$ & $2.22 \pm 0.10^{c}$ & $2.03 \pm 0.01^{b}$ & $60.45 \pm 0.84^{\mathrm{a}}$ & $16.58 \pm 0.45^{a}$ & $0.67 \pm 0.05^{\mathrm{a}}$ & $0.41 \pm 0.03^{\mathrm{a}}$ & $20.06 \pm 0.56^{b}$ & $62.67 \pm 0.94 a$ & $17.25 \pm 0.49^{\mathrm{a}}$ \\
\hline & & 28 & $19.24 \pm 0.62^{\mathrm{a}}$ & $2.61 \pm 0.20^{\mathrm{abc}}$ & $2.17 \pm 0.14^{\mathrm{a}}$ & $57.96 \pm 1.82^{\mathrm{a}}$ & $17.08 \pm 0.73^{\mathrm{a}}$ & $0.71 \pm 0.04^{\mathrm{a}}$ & $0.27 \pm 0.05^{\mathrm{a}}$ & $21.68 \pm 0.79^{a}$ & $60.57 \pm 1.66^{a b}$ & $17.79 \pm 0.78^{\mathrm{a}}$ \\
\hline & \multirow{5}{*}{$5^{\circ} \mathrm{C}$} & 0 & $20.05 \pm 1.80^{\mathrm{a}}$ & $2.48 \pm 0.38^{\mathrm{ab}}$ & $2.06 \pm 0.07^{\mathrm{a}}$ & $57.57 \pm 1.92^{\mathrm{a}}$ & $16.79 \pm 0.24^{\mathrm{a}}$ & $0.67 \pm 0.01^{\mathrm{a}}$ & $0.37 \pm 0.14^{\mathrm{a}}$ & $22.15 \pm 1.15^{\mathrm{a}}$ & $60.38 \pm 1.35^{a}$ & $17.46 \pm 0.25^{\mathrm{a}}$ \\
\hline & & 7 & $18.85 \pm 1.01^{\mathrm{a}}$ & $2.64 \pm 0.20^{\mathrm{ab}}$ & $2.06 \pm 0.05^{\mathrm{a}}$ & $58.77 \pm 1.00^{\mathrm{a}}$ & $16.63 \pm 0.51^{\mathrm{ab}}$ & $0.62 \pm 0.01^{b}$ & $0.39 \pm 0.04^{\mathrm{a}}$ & $21.30 \pm 1.00^{\mathrm{a}}$ & $61.41 \pm 0.83^{\mathrm{a}}$ & $17.25 \pm 0.52^{\mathrm{at}}$ \\
\hline & & 14 & $18.64 \pm 1.04^{\mathrm{a}}$ & $2.36 \pm 0.19^{b}$ & $2.04 \pm 0.10^{\mathrm{a}}$ & $58.89 \pm 0.99^{\mathrm{a}}$ & $17.08 \pm 0.14^{\mathrm{a}}$ & $0.63 \pm 0.01^{\mathrm{ab}}$ & $0.36 \pm 0.11^{\mathrm{a}}$ & $21.05 \pm 0.98^{\mathrm{a}}$ & $61.24 \pm 1.09^{\mathrm{a}}$ & $17.72 \pm 0.15^{\mathrm{a}}$ \\
\hline & & 21 & $19.73 \pm 0.62^{\mathrm{a}}$ & $2.92 \pm 0.18^{a}$ & $2.02 \pm 0.06^{\mathrm{a}}$ & $58.29 \pm 0.58^{a}$ & $16.09 \pm 0.39^{c}$ & $0.61 \pm 0.04^{b}$ & $0.37 \pm 0.05^{\mathrm{a}}$ & $22.12 \pm 0.60^{a}$ & $61.21 \pm 0.43^{a}$ & $16.70 \pm 0.43^{b}$ \\
\hline & & 28 & $19.17 \pm 0.46^{\mathrm{a}}$ & $2.91 \pm 0.22^{a}$ & $2.00 \pm 0.08^{\mathrm{a}}$ & $58.18 \pm 0.70^{\mathrm{a}}$ & $16.80 \pm 0.28^{\mathrm{a}}$ & $0.63 \pm 0.02^{b}$ & $0.34 \pm 0.09^{\mathrm{a}}$ & $21.51 \pm 0.46^{a}$ & $61.09 \pm 0.50^{\mathrm{a}}$ & $17.43 \pm 0.30^{\mathrm{a}}$ \\
\hline \multirow{10}{*}{ Chétoui } & \multirow{5}{*}{ AT } & 0 & $12.04 \pm 0.70^{\mathrm{a}}$ & $0.21 \pm 0.06^{a}$ & $2.84 \pm 0.04^{\mathrm{a}}$ & $66.23 \pm 0.69^{a}$ & $17.65 \pm 0.12^{\mathrm{a}}$ & $0.61 \pm 0.01^{a}$ & $0.42 \pm 0.02^{\mathrm{a}}$ & $15.29 \pm 0.71^{\mathrm{a}}$ & $66.44 \pm 0.64^{\mathrm{ab}}$ & $18.27 \pm 0.13^{\mathrm{a}}$ \\
\hline & & 7 & $12.77 \pm 0.33^{\mathrm{a}}$ & $0.4 \pm 0.07^{\mathrm{a}}$ & $2.64 \pm 0.12^{\mathrm{a}}$ & $65.06 \pm 0.44^{\mathrm{a}}$ & $18.05 \pm 0.58^{a}$ & $0.65 \pm 0.01^{\mathrm{a}}$ & $0.37 \pm 0.04^{\mathrm{ab}}$ & $15.77 \pm 0.43^{\mathrm{a}}$ & $65.46 \pm 0.37^{b}$ & $18.70 \pm 0.58^{\mathrm{a}}$ \\
\hline & & 14 & $11.74 \pm 0.35^{\mathrm{a}}$ & $0.43 \pm 0.34^{\mathrm{a}}$ & $2.93 \pm 0.36^{a}$ & $66.14 \pm 1.11^{\mathrm{a}}$ & $17.86 \pm 0.57^{\mathrm{a}}$ & $0.64 \pm 0.03^{\mathrm{a}}$ & $0.26 \pm 0.13^{b}$ & $14.93 \pm 0.46^{a}$ & $66.57 \pm 0.80^{a}$ & $18.50 \pm 0.60^{\mathrm{a}}$ \\
\hline & & 21 & $12.17 \pm 1.26^{\mathrm{a}}$ & $0.73 \pm 0.34^{\mathrm{a}}$ & $2.62 \pm 0.08^{\mathrm{a}}$ & $65.20 \pm 0.31^{\mathrm{a}}$ & $18.12 \pm 0.58^{a}$ & $0.72 \pm 0.13^{\mathrm{a}}$ & $0.42 \pm 0.08^{\mathrm{a}}$ & $15.21 \pm 1.19^{\mathrm{a}}$ & $65.93 \pm 0.58^{\mathrm{ab}}$ & $18.85 \pm 0.71^{\mathrm{a}}$ \\
\hline & & 28 & $11.62 \pm 0.36^{\mathrm{a}}$ & $0.50 \pm 0.46^{\mathrm{a}}$ & $2.76 \pm 0.08^{\mathrm{a}}$ & $66.17 \pm 0.17^{\mathrm{a}}$ & $17.86 \pm 0.49^{\mathrm{a}}$ & $0.67 \pm 0.06^{\mathrm{a}}$ & $0.45 \pm 0.03^{\mathrm{a}}$ & $14.82 \pm 0.26^{\mathrm{a}}$ & $66.67 \pm 0.32^{\mathrm{a}}$ & $18.53 \pm 0.54^{\mathrm{a}}$ \\
\hline & \multirow{5}{*}{$5^{\circ} \mathrm{C}$} & 0 & $12.04 \pm 0.7^{\mathrm{a}}$ & $0.21 \pm 0.06^{\mathrm{a}}$ & $2.84 \pm 0.04^{\mathrm{a}}$ & $66.23 \pm 0.69^{a}$ & $17.65 \pm 0.12^{\mathrm{a}}$ & $0.61 \pm 0.01^{\mathrm{ab}}$ & $0.42 \pm 0.02^{\mathrm{a}}$ & $15.29 \pm 0.71^{\mathrm{a}}$ & $66.44 \pm 0.64^{\mathrm{a}}$ & $18.27 \pm 0.13^{b}$ \\
\hline & & 7 & $12.11 \pm 021^{a}$ & $0.51 \pm 0.35^{\mathrm{a}}$ & $2.79 \pm 0.06^{a}$ & $65.45 \pm 0.30^{a}$ & $18.14 \pm 0.13^{\mathrm{a}}$ & $0.63 \pm 0.02^{\mathrm{a}}$ & $0.30 \pm 0.02^{b}$ & $15.23 \pm 0.23^{a}$ & $65.97 \pm 0.20^{a}$ & $18.76 \pm 0.15^{\mathrm{a}}$ \\
\hline & & 14 & $12.02 \pm 0.73^{\mathrm{a}}$ & $0.48 \pm 0.03^{\mathrm{a}}$ & $2.75 \pm 0.10^{\mathrm{a}}$ & $66.05 \pm 0.85^{a}$ & $17.65 \pm 0.22^{\mathrm{a}}$ & $0.63 \pm 0.02^{\mathrm{ab}}$ & $0.42 \pm 0.03^{\mathrm{a}}$ & $15.19 \pm 0.71^{\mathrm{a}}$ & $66.53 \pm 0.88^{a}$ & $18.28 \pm 0.24^{b}$ \\
\hline & & 21 & $12.2 \pm 0.72^{\mathrm{a}}$ & $0.37 \pm 0.12^{\mathrm{a}}$ & $2.73 \pm 0.04^{\mathrm{a}}$ & $66.45 \pm 0.62^{\mathrm{a}}$ & $17.22 \pm 0.38^{\mathrm{a}}$ & $0.60 \pm 0.02^{b}$ & $0.41 \pm 0.07^{\mathrm{a}}$ & $15.35 \pm 0.63^{\mathrm{a}}$ & $66.82 \pm 0.50^{\mathrm{a}}$ & $17.81 \pm 0.40^{b}$ \\
\hline & & 28 & $12.39 \pm 0.38^{\mathrm{a}}$ & $0.29 \pm 0.06^{a}$ & $2.73 \pm 0.13^{\mathrm{a}}$ & $65.86 \pm 0.65^{a}$ & $17.68 \pm 0.28^{\mathrm{a}}$ & $0.61 \pm 0.01^{\mathrm{ab}}$ & $0.43 \pm 0.00^{\mathrm{a}}$ & $15.55 \pm 0.28^{\mathrm{a}}$ & $66.16 \pm 0.59^{\mathrm{a}}$ & $18.29 \pm 0.29^{b}$ \\
\hline EVOO & & & $7.5-20.0$ & $0.3-3.5$ & $0.5-5$ & $55.0-83.0$ & $3.5-21.0$ & $\leq 1.0$ & $\leq 0.6$ & - & - & - \\
\hline
\end{tabular}

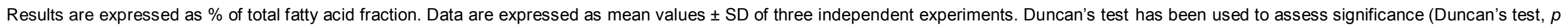
$=0.05$ ). Significant differences in the same row are shown by different letters. TS: Temperature storage; PS: period storage; AT: ambient temperature; EVOO: extra virgin olive oil.

their high percentage in oleic acid. It can also be seen that Chemlali olive oils presented the highest values in saturated fatty acids (SFA), essentially due to their high content of palmitic acid. The linoleic acid, which is much more susceptible to oxidation than MUFA, is the main polyunsaturated fatty acid (PUFA). Chétoui olive oils were found to have a higher percentage in PUFA due to their high content in linoleic acid. During olive storage at $5^{\circ} \mathrm{C}$ and ambient temperature, the fatty acid com-position did not vary. This result is in agreement with the findings of Pereira et al. (2002). It is known that the fatty acid composition remains stable or varies slightly according to many factors, namely, climatic conditions (Aganchich et al., 2008). In addition, the percentages of the fatty acids in the all analysed oils are close to the International Olive Oil
Council norm and they belonged to the extra virgin category.

\section{Change in total phenol content}

Polyphenols are important antioxidants which protect biological systems against oxygen radicals (Bendini et al., 2007). These substances also 
Table 3. Total phenols oxidative stability and RSA of the studied olive oil samples.

\begin{tabular}{|c|c|c|c|c|c|}
\hline Variety & TS & PS (days) & Total phenol & Oxidative stability & RSA \\
\hline \multirow[t]{10}{*}{ Chemlali } & AT & 0 & $728.52 \pm 67.40^{\mathrm{a}}$ & $47.06 \pm 2.44^{\mathrm{a}}$ & $87.40 \pm 4.66^{a}$ \\
\hline & & 1 & $276.21 \pm 18.95^{\mathrm{b}}$ & $34.36 \pm 2.09^{b}$ & $62.56 \pm 4.20^{b}$ \\
\hline & & 2 & $131.04 \pm 12.76^{c}$ & $14.68 \pm 1.18^{\mathrm{C}}$ & $52.54 \pm 3.10^{\mathrm{C}}$ \\
\hline & & 3 & $88.69 \pm 7.59^{c}$ & $12.48 \pm 0.67^{\mathrm{cd}}$ & $39.28 \pm 2.57^{d}$ \\
\hline & & 4 & $79.81 \pm 6.66^{\mathrm{C}}$ & $11.07 \pm 1.31^{d}$ & $22.79 \pm 1.47^{\mathrm{e}}$ \\
\hline & $5^{\circ} \mathrm{C}$ & 0 & $728.52 \pm 67.40^{\mathrm{a}}$ & $47.06 \pm 2.44^{a}$ & $87.40 \pm 4.66^{\mathrm{a}}$ \\
\hline & & 1 & $658.59 \pm 44.09^{b}$ & $44.37 \pm 1.57^{\mathrm{a}}$ & $84.17 \pm 3.77^{\mathrm{ab}}$ \\
\hline & & 2 & $628.70 \pm 21.51^{\mathrm{b}}$ & $46.72 \pm 1.21^{\mathrm{a}}$ & $79.57 \pm 2.67^{\mathrm{bc}}$ \\
\hline & & 3 & $469.26 \pm 16.85^{\mathrm{c}}$ & $43.44 \pm 3.18^{\mathrm{a}}$ & $75.89 \pm 3.66^{\mathrm{c}}$ \\
\hline & & 4 & $149.39 \pm 5.91^{d}$ & $17.73 \pm 0.54^{b}$ & $37.44 \pm 1.66^{\mathrm{d}}$ \\
\hline \multirow[t]{10}{*}{ Chétoui } & AT & 0 & $862.19 \pm 81.59^{a}$ & $58.76 \pm 2.21^{\mathrm{a}}$ & $92.41 \pm 0.76^{a}$ \\
\hline & & 1 & $437.04 \pm 33.92^{b}$ & $47.89 \pm 3.12^{b}$ & $68.82 \pm 1.24^{\mathrm{b}}$ \\
\hline & & 2 & $224.27 \pm 25.81^{\mathrm{c}}$ & $20.14 \pm 1.74^{\mathrm{C}}$ & $57.69 \pm 2.09^{c}$ \\
\hline & & 3 & $209.33 \pm 4.22^{c}$ & $16.19 \pm 2.16^{c d}$ & $44.71 \pm 2.88^{\mathrm{d}}$ \\
\hline & & 4 & $187.91 \pm 5.03^{c}$ & $13.27 \pm 1.73^{d}$ & $34.45 \pm 1.81^{\mathrm{e}}$ \\
\hline & $5^{\circ} \mathrm{C}$ & 0 & $862.19 \pm 81.59^{a}$ & $58.76 \pm 2.21^{a}$ & $92.41 \pm 0.76^{\mathrm{a}}$ \\
\hline & & 1 & $834.53 \pm 38.88^{\mathrm{a}}$ & $55.32 \pm 1.85^{\mathrm{a}}$ & $87.44 \pm 3.87^{\mathrm{ab}}$ \\
\hline & & 2 & $756.43 \pm 103.20^{\mathrm{ab}}$ & $56.23 \pm 3.50^{\mathrm{a}}$ & $82.32 \pm 1.57^{\mathrm{bc}}$ \\
\hline & & 3 & $648.36 \pm 40.46^{b}$ & $54.46 \pm 1.50^{\mathrm{a}}$ & $78.46 \pm 4.64^{\circ}$ \\
\hline & & 4 & $308.25 \pm 15.62^{c}$ & $28.86 \pm 2.72^{b}$ & $46.90 \pm 1.30^{d}$ \\
\hline
\end{tabular}

Data are expressed as mean values \pm SD of three independent experiments. Duncan's test has been used to assess significance (Duncan's test, $p=0.05$ ). Significant differences in the same row are shown by different letters. TS: Temperature storage; PS: period storage; AT: ambient temperature; EVOO: extra virgin olive oil.

contribute to oil stability and are responsible for the fragrance and peculiar flavour of virgin olive oil (Servili et al., 2004). Table 3 shows the changes in the total phenol content of the oils obtained from olives stored at different temperatures. In the oils extracted from fruits stored at ambient temperature, the total phenol content underwent a remarkable decrease as early as the first week of storage and at the end of experimentation trial (28 days), it remains about only 20 and $10 \%$ of their Initial contents for Chétoui and Chemlali cultivars, respectively. By contrast, oil phenols from stored olives kept at $5^{\circ} \mathrm{C}$ reduced slightly during the first 21 days of storage after which they decreased considerably. Results of this study agree with findings of previous workers. Clodoveo et al. (2007) found that oil obtained from olive of Coratina cultivar kept at the higher temperature and in ambient air had their total phenol content decreased. The losses of phenols could be as a result of the rise of oxidative state of fruits. In fact, olives contain oxido-reductases, such as polyphenoloxidase and peroxidase that may oxidize polyphenols and impair the health-related qualities and sensory characteristics of olive oil (Servili et al., 2003); the activity of these enzymes is known to decrease at low temperatures. The results we obtained are consistent with these observations. On the other hand, compared to Chemlali cultivar, Chétoui olive oils samples were found to show a higher content in total phenols throughout the storage. This finding may be attributed to genetic factors between the two varieties such as differences in the catabolic pathways of these compounds during fruit storage.

\section{Change in oxidative stability}

The fatty acids of virgin olive oil are mainly monounsaturated. This fact and the presence of antioxidant compounds such as phenols and carotenoids make virgin olive oil more stable than other edible oils (Salvador et al., 2001). Some authors have estimated their contribution to oil stability, that of phenolic coumpounds being around $30 \%$, fatty acids $27 \%$ and carotenoids $6 \%$ (Aparicio et al., 1999). Oxidative stability of studied olive oils behaved similarly to the evolution of total phenols 
during fruit storage (Table 3). Thus, it decreased markedly in oils from olives stored at ambient temperature whereas the olive storage at $5^{\circ} \mathrm{C}$ did not affect the oil stability during the first 21 days after which it decreased significantly. These trends were confirmed by the high positive correlations found between total phenols and oxidative stability in Chétoui oils $\left(r^{2}=0.87, r^{2}=0.92\right)$ obtained from stored olives at ambient temperature and $5^{\circ} \mathrm{C}$, respectively and in Chemlali oils $\left(r^{2}=0.89, r^{2}=0.89\right)$ obtained from stored olives at ambient temperature and $5^{\circ} \mathrm{C}$, respectively. In addition, the levels of Chétoui oil stability are higher than those of Chemlali cultivar during all the period of olive storage as well at the ambient temperature as at $5^{\circ} \mathrm{C}$. This characteristic could result from the fact that these oils are richer in oleic acid and polyphenols.

\section{Change in the oil radical scavenging capacity}

The antioxidant activity of studied olive oils, evaluated by the measurement of their radical scavenging activity (RSA), is shown in Table 3. As observed in total phenol content and oxidative stability, the values of RSA of olive oils extracted from fruits kept at ambient temperature decreased markedly during storage whereas in oils extracted from olives kept at $5^{\circ} \mathrm{C}$, a slight decrease was observed during the first 21 days of storage after which the diminution became more accentuated. This result on the RSA verified the relation between the oil stability and antioxidant compounds discussed above. Indeed the high positive correlations observed between total phenols and the RSA in Chétoui oils $\left(r^{2}=0.88, r^{2}=0.98\right)$ obtained from stored olives at ambient temperature and $5^{\circ} \mathrm{C}$, respectively and in Chemlali oils $\left(r^{2}=0.90, r^{2}=0.95\right)$ obtained from stored olives at ambient temperature and $5^{\circ} \mathrm{C}$, respectively confirm their active contribution to the oil stability. Results of this study agree with findings of previous works. Owen et al. (2000) observed that the antioxidant capacity of the olive oil was significantly correlated with the total phenolic content. Other studies have also concluded that much of the total antioxidant activity of different samples is related to their phenolic content (Borbalan et al., 2003; Ferández-Pachón et al., 2004). In addition, the RSA values of Chétoui olive oils were all higher than those of Chemlali cultivar. This characteristic may be attributed to their higher antioxidant amount such as phenol compounds.

\section{Conclusions}

It appears clearly that oil quality of Chemlali olives deteriorated more rapidly during fruit storage than that of Chétoui olives. Based on the results of chemical quality parameters such as free acidity and UV absorption (K232 and K270), the olive oils lost the extra virgin classification more rapidly for Chemlali cultivar when olives were stored at ambient temperature. This experimentation pro-vided also evidence that oils obtained from olives stored at $5^{\circ} \mathrm{C}$ preserved the best characteristics compared to those obtained from olives kept at ambient temperature because, even after 21 days of cold storage, oil obtained from these olives was of good quality for the two olive cultivars studied.

\section{REFERENCES}

Aganchich B, El Antari A, Wahbi S, Tahi H, Wakrim R, Serraj R (2008). Fruit and oil quality of mature olive trees under partial rootzone drying in field conditions. Grasas. Aceites, 59(3): 225-233.

Agar IT, Hess-Pierce B, Sourour MM, Kader AA (1998). Quality of fruit and oil of black-ripe olives is influenced by cultivar and storage period. J. Agric. Food Chem. 46: 3415-3421.

Alberti A, Amorati R, Campredon M, Lucarini M, Macciantell D, Pedulli GF (2009). Antioxidant activity of some simple phenols present in olive oil. Acta Alimentaria, 38(4): 427-436.

Aparicio R, Roda L, Albi MA, Gutiérrez F (1999). Effect of Various Compounds on Virgin Olive Oil Stability Measured by Rancimat. J. Agric. Food Chem. 47: 4150-4155.

Bandelj D, Jakse J, Javornik B (2002). DNA Fingerprinting of olive varieties by microsatellite markers. Food Technol. Biotechnol. 40(3): 185-190.

Bendini A, Cerretani L, Carrasco-Pancorbo A, Gómez-Caravaca AM, Segura-Carretero A, Fernández-Gutiérrez A,Lercker G (2007). Phenolic molecules in virgin olive oils: a survey of their sensory properties, health effects, antioxidant activity and analytical methods. Molecules, 12: 1679-1719.

Borbalan AM, Zorro L, Guillen DA, Barroso CG (2003). Study of the polyphenol content of red and white grape varieties by liquid chromatography-mass spectrometry and its relationship to antioxidant power. J. Chromatogr. A, 1012: 31-38.

Boskou D (1996). Olive Oi: Chemistry and Technology. AOCS Press, Champaign, IL. USA. pp. 85-127.

Castellano JM, García JM, Morilla A, Perdiguero S, Gutiérrez F (1993). Quality of Picual olive fruits stored under controlled atmospheres. J. Agric. Food Chem. 41: 537-539.

Ceci LN, Carelli AA (2010). Relation between oxidative stability and composition in Argentinian olive oils. J. Am. Oil Chem. Soc. (in press).

Cicerale S, Lucas L, Keast R (2010). Biological activities of phenolic compounds present in virgin olive oil. Int. J. Mol. Sci. 11: 458-479.

Clodoveo M, Delcuratolo D, Gómes T, Colelli G (2007). Effect of different temperatures and storage atmospheres on Coratina olive oil quality. Food Chem. 102: 571-576.

Codex Alimenarius Commission (2007). Codex commitee on fats and oils. Twentieth Session. London. United Kingdom. 19-23 February. www.codexalimenarius.net.

Fernández-Pachón MS, Villaño D, García-Parrilla MC, Troncoso AM (2004). Antioxidant activity of wines and relation with their polyphenolic composition. Anal. Chim. Acta, 513: 113-118.

Gandul-Rojas B, Roca Lopez-Cepero M, Carmona-Ramon Cand Minguez-Mosquera Ml (1999). Stability of chlorophyll pigments during storage of virgin olive oil in PFT Sevilla: Proceedings of the $1^{\text {st }}$ International Congress on Pigments in Food Technologie. Sevilla Spain. pp. 271-275

Garcia JM, Yousfi K (2006). The postharvest of mill olives. Grasas Aceites, 57:16-24

Garcia, JM, Gutiérrez F, Castellano JM, Perdiguero S, Morilla A, Albi MA (1996). Influence of storage temperature on fruit ripening and olive oil quality. J. Agric. Food Chem. 44: 264-267.

Gigon F, Le Jeune R (2010). Huile d'olive, Olea europaea L. Phytothérapie, 8: 129-135.

Gimeno E, Fito M, Lamuela-Raventos RM, Castellote Al, Covas M, Farré M (2002). Effect of ingestion of virgin olive oil on human lowdensity lipoprotein composition. Eur. J. Clin. Nutr. 56: 114-120.

Gutiérrez F (1989). Determinación de la estabilidad oxidativa de aceites 
de oliva vírgenes: Comparación entre del método A.O.M. yel método Rancimat. Grasas Aceites, 40: 1-5.

Gutiérrez F, Perdiguero S, García JM, Castellano JM (1992). Quality of oils from olives stored under controlled atmosphere. J. Am. Oil Chem. Soc. 69: 1215-1218.

Kalantzakis G, Blekas G, Pegklidou K, Boskou D (2006). Stability and radicalscavenging activity of heated olive oil and other vegetable oils. Eur. J. Lipid Sci. Technol. 108: 329-335.

Kiritsakis AK, Nuous GD, Polymenoupoulos Z, Thomai T, Sfakiotakis EY (1998). Effect of fruit storage conditions on olive oil quality. J. Am. Oil Chem. Soc. 75: 721-724.

Kiritsakis AK (1998). Olive Oil from the tree to the table. Food Nutr. Press: Trumbull, CT. p 348.

Koprivnjak O, Conte L, Totis N (2002). Influence of olive fruit storage in bags on oil quality and composition of volatile compounds. Food Technol. Biotechnol. 40(2): 129-134.

Matos LC, Cunha SC, Amaral JS, Pereira JA, Andrade PB, Seabra RM and Oliveira, B.P.P (2007). characterization of three varietal olive oils (Cvs. Cobrancosa, Madural and Verdeal Transmontana) extracted from olives with different maturation indices. Food Chem. 102: 406414.

Medeiros MD (2001). Olive oil and health benefits In Wildman REC (eds). The Handbook of Nutraceuticals and Functional Foods. CRC Press. Boca Raton. pp. 261-267

Menendez JA, Vazquez-Martin A, Oliveras-Ferraros C, Rocio GV, Alergia CP, Alberto FG and Antonio SC (2009). Extra-virgin olive oil polyphenols inhibit HER2 (erbB-2)-induced malignant transformation in human breast epithelial cells: relationship between the chemical structures of extravirgin olive oil secoiridoids and lignans and their inhibitory activities on the tyrosine kinase activity of HER2. Int. J. Oncol. 34(1): 43-51.

Minguez-Mosquera Ml, Rejano-Navarro L, Gandul-Rojas B, SánchezGómez AH, Garrido-Fernández J (1991). Color-pigment correlation in virgin olive oil. J. Am. Oil Chem. Soc. 68: 332-336.

Olias JM, Garcia JM (1997). Olive. In Mitra SK (Eds). Postharvest physiology and storage of tropical and subtropical fruits. CAB International. Wallingford, UK. pp. 229-243.

Oueslati I, Anniva C, Daoud D, Tsimidou MZ, Zarrouk M (2009). Virgin olive oil (VOO) production in Tunisia: The commercial potential of the major olive varieties from the arid Tataouine zone. Food Chem. 112: 733-741.
Owen RW, Giacosa A, Hull WE, Haubner R, Spiegelhalder B, Bartsch H (2000). The antioxidant/anticancer potential of phenolic compounds isolated from olive oil. Eur. J. Cancer, 36: 1235-1247.

Ranalli A, De Mattia G, Patumi M, Proietti P (1999). Quality of virgin olive oil as influenced by origin area. Grasas Aceites, 50: 249-259.

Ranalli A, Modesti G (1999). Processing technologies and biotechnologies affect the composition of green and yellow lipochromes and the chromatic features of virgin olive oil. In PFT Sevilla: Proceedings of the $1^{\text {st }}$ International Congress on Pigments in Food Technologie, Sevilla Spain. pp. 239-245

Salvador MD, Aranda F, Fregapane G (2001). Influence of fruit ripening on Cornicabra virgin olive oil quality: a study of four crop seasons. Food Chem. 73: 45-53.

Servili M, Selvaggini S, Esposto A, Taticchi G, Montedoro GF,Morozzi $G$ (2004). Health and sensory properties of virgin olive oil hydrophilic phenols: Agronomic and technological aspects of production that affect their occurrence in the oil. J. Chromatogr. A 1054: 113-127.

Servili M, Selvaggini R, Taticchi A, Esposto S, Montedoro GF (2003). Volatile compounds and phenolic composition of virgin olive oil: optimization of temperature and time of exposure of olive pastes to air contact during the mechanical extraction process. J. Agric. Food Chem. 51(27): 7980-7988.

Trigui $A$, Msallem $M$, Yengui $A$, Khecherem J, Meliène $A$, Malek $S$, Bousselmi A, Samet A, Trabelsi E.B (2002). Oliviers de Tunisie: Variétés autochtones et types locaux, vol. 1, Reluire d'Art, Sfax, Tunisie.

Turki A, Mahjoub A (1995). Effet du mode de stockage des olives sur la qualité de l'huile. Micro. Hyg. Ali. 18: 34-40. 